МЕДИЦИНА

MEDICINE

DOI 10.31489/2021BMG2/70-75

UDC 616-018:616:379-008.64

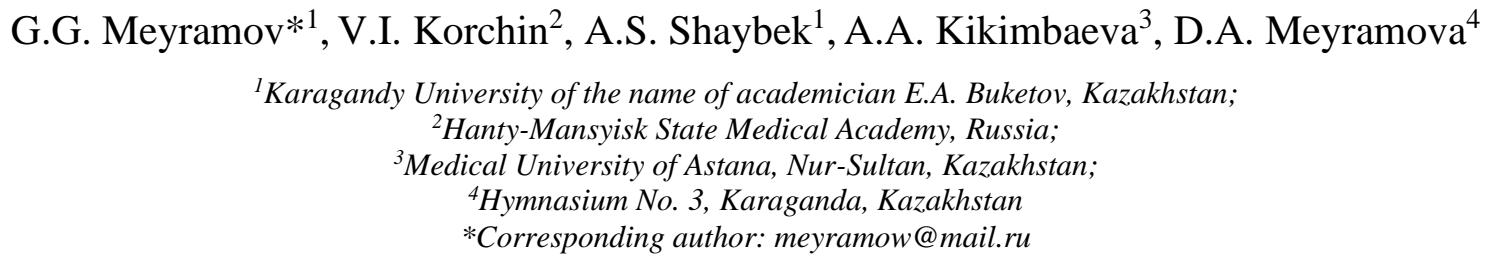

\title{
On the mechanisms of damaging effect of diabetogenic chelators on the endothelium of blood capillaries in pancreatic islets
}

\begin{abstract}
Authors showed that administration of diabetic zinc binders (DZC) to animals is accompanied not only by destruction and death of B cells, but also by the development of morphological changes in the capillaries of pancreatic islets at the site of contact with B cells (destruction of the capillary endothelium sites, change in the shape of the capillary lumen, erythrocytes adhesion, perivascular edema, hyperemia). Vascular changes are usually late complications of diabetes. To answer the question: are the described changes in islet capillaries a late complication of diabetes (1) or is it the result of the direct damaging effect of DZC (2), low doses of DZC that do not cause diabetes in animals are used, forming a toxic zinc-dithizone complex only at B-pole cells in contact with the capillary wall. It was shown that in this case, the capillary wall is damaged in the absence of diabetes, which indicates a direct damaging effect of DZC not only on B-cells but also on the endothelium of islet capillaries. This is not a direct cause of the development of these forms of diabetes, but may be accompanied by circulatory disorders in pancreatic islets and a worsening of the course of the disease.
\end{abstract}

Keywords: B-cells, endothelium, capillaries, diabetogenic zinc binding chemicals, histofluorimetric complex.

\section{Introduction}

It is known that diabetes mellitus is accompanied by the development of late vascular complications $[1,2]$. This is not only about violations of the main arteries, but also the vessels of the kidneys, eyes and other organs and tissues.

Previously attention was paid to maximal concentration of zinc and granules of deposited insulin in pancreatic B-cells located on the pole of cell contacted to the wall of the islet blood capillaries and significantly exceeds its content in other parts of the cytoplasm of B-cells (Fig. 1.1 and 1.2) where hormone exocytosis occurs in the blood [3]. Attention was also drawn to the fact that the histotopography of the location of zinc after administration of Dithizon and the formation of the Zinc-Dithizon complex coincides with the histotopography of insulin in B-cells [4].

This prompted the thought of whether this complex does not affect the endothelial cells of the islet capillaries. In the case of positive result it would be possible to put forward the assumption of a more universal toxic effect of this complex not only on B cells, but also on some other cells of the body.

\section{Experimental}

Considering the established properties of the Zinc-DZC complex to exert a damaging effect on B-cells causing their death, the question should be asked: is this complex capable of exerting a similar effect on capillary wall cells, in particular, endothelial cells? In order to answer this question, experiments were conducted 
on 17 outbred rabbits, which were treated using of various doses of Dithizone. Animals were divided into 3 groups.

Group 1. Injection to 8 rabbits of diabetogenic dose of water-ammonium solution of Dithizon (DZ) $46.6-49.3 \mathrm{mg} / \mathrm{kg}$, after which 4 (subgroup 1) of them were killed by air embolia $10 \mathrm{~min}$. later. Frozen sections $7 \mu \mathrm{m}$ and $4 \mu \mathrm{m}$ were investigated using dark field microscopy. In 4 other animals (subgroup 2), blood glucose levels were determined over the next 3,6, and 9 days. After that, the pancreas was removed and histological sections of the pancreas fixed in Bouin; staining by specific for insulin and zinc histochemical methods and of histostructure of islets as of content of deposited insulin in the B-cells by using of histological methods to study the state of the histostructure.

Finally, 3 animals (subgroup 3) were killed $2 \mathrm{~h}$ after injection of DZ; sections of fixed pancreas were also stained using of aldehyde-fuchsin $[5,6]$ to analyze state of islet's capillaries and treated by high specific fluorescent method for staining zinc ions in B-cells [7, 8].

Group 2. Injection to 6 animals of not diabetogenic minimal dose of Dithizon as $12-15 \mathrm{mg} / \mathrm{kg}$, which is able to bind zinc with the formation of the Zinc-Dithizon complex only at the sites of the greatest accumulation of insulin, that is, in B-cells that are closely contact to the capillary wall. 3 of them were killed after 10 min. Frozen sections $6 \mu \mathrm{m}$ were investigated using dark field microscopy. In the other 3 animals blood glucose levels were measured over the next 3,6, and 9 days, after which the pancreas was tissue fixed in the Bouin solution and were stained using of histological and histochemical methods to assess the state of the histostructure and the content of deposited insulin in B cells.

\section{Results}

Group 1, subgroup 1: A) investigation of aldehyde-fuchsin stained sections of pancreas of intact animals: numerous islets without any changes of histostructure and a large amount of deposited insulin in B-cells. B) visual analysis of histotopography of the location of hormone showed the maximum concentration of deposited insulin in part of B-cells contacted to the blood capillaries (Fig. 1.1, 1.2, 1.3, 1.4 blue color of insulin and purple granules of zinc-insulin complex).

Analysis of the content of the zinc-insulin complex in B-cells of animals of subgroup 1 in the form of red complex with Dithizon clearly confirms the disposition of zinc in the same place as insulin around the walls of the islet capillaries (Fig. 1.5).

After injection of Dithizon to animals of subgroup 2 (control), hyperglycemia was increased from $9.7 \pm 0.5 \mathrm{mM}$ on day 3 until $14.3 \pm 0.5 \mathrm{mM}$ on day 6 and $16.7 \pm 0.6 \mathrm{mM}$ on day 9 (Table 1 ), which corresponds to type 1 diabetes. Histostructure of islets: destruction and necrosis of B-cells, vacuole dystrophia and degranulation of B-cells.

Table 1

Blood glucose concentration in rabbits after injection of various doses of Dithizon (mmol/l)

\begin{tabular}{|c|c|c|c|c|l|}
\hline Conditions & \multirow{2}{*}{ Baseline } & \multicolumn{4}{|c|}{ Period after injection of DZ } \\
\cline { 3 - 6 } & 3 days & 6 days & $8-9$ days & \\
\hline Intact animals & $4.8 \pm 0.5$ & - & $5.1 \pm 0.4$ & $4.9 \pm 0.6$ & Histostructure and insulin content without changes \\
\hline $\begin{array}{c}\text { Dithizon } \\
49.3 \mathrm{mg} / \mathrm{kg}\end{array}$ & $5.0 \pm 0.4$ & $9.7 \pm 0.5$ & $14.3 \pm 0.5$ & $16.7 \pm 0.6^{*}$ & $\begin{array}{l}\text { Destruction of B-cells, marked decreasing of amount of } \\
\text { insulin in B-cells }\end{array}$ \\
\hline $\begin{array}{c}\text { Dithizon } \\
12.6 \mathrm{mg} / \mathrm{kg}\end{array}$ & $5.2 \pm 0.3$ & $6.2 \pm 0.3$ & $5.6 \pm 0.5$ & $5.3 \pm 0.7$ & $\begin{array}{l}\text { Partial destruction of B-cells located around capillaries; } \\
\text { partial alteration of endothelium of capillaries, hyperemia, } \\
\text { stasis, agglutination of erythrocytes }\end{array}$ \\
\hline
\end{tabular}

Note. ${ }^{*} \mathrm{p} \leq 0.005$ in compared to baseline level

Analysis of the state of histostructure of pancreas of animals after administration of low doses of Dithizon showed the following: numerous islets without visible changes of histostructure were found in sections of pancreas. Insulin content in B-cells also did not visually differ from that observed in islets of intact animals (Fig. 1.6, 2.1, 2.2). In islet's capillaries there are signs of damage and destruction of the apical part of B-cells contacted to the capillaries' wall, which is understandable, given that in this part of B-cells there is concentrated a maximum of the amount of insulin deposited in the form of a zinc-insulin complex after administration of small doses of Dithizon. The expansion of capillaries, in some places the presence of signs of perivascular edema, the presence in places of a poorly visible contour of the basal membrane of the endothelium often deformed and damaged were noted (Fig. 2.1, 2.2). 
It is known that vascular complications in diabetes mellitus developed as late complications developed in human many years later after diagnosis of diabetes.

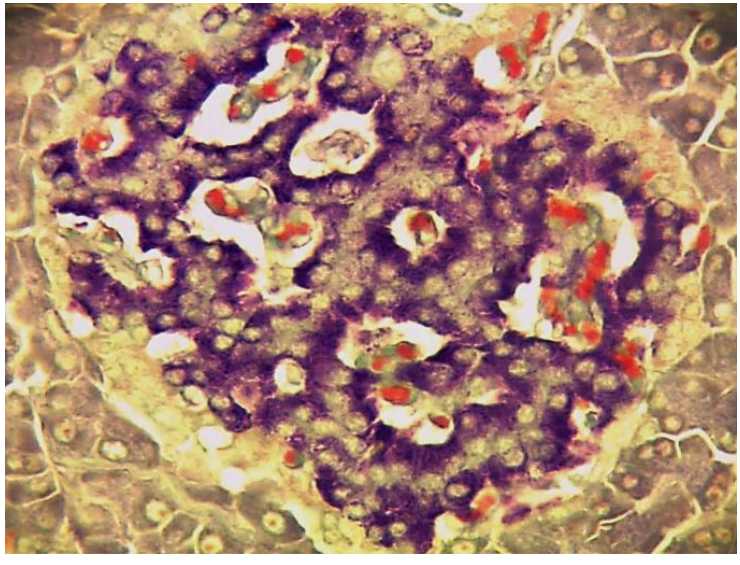

1.1

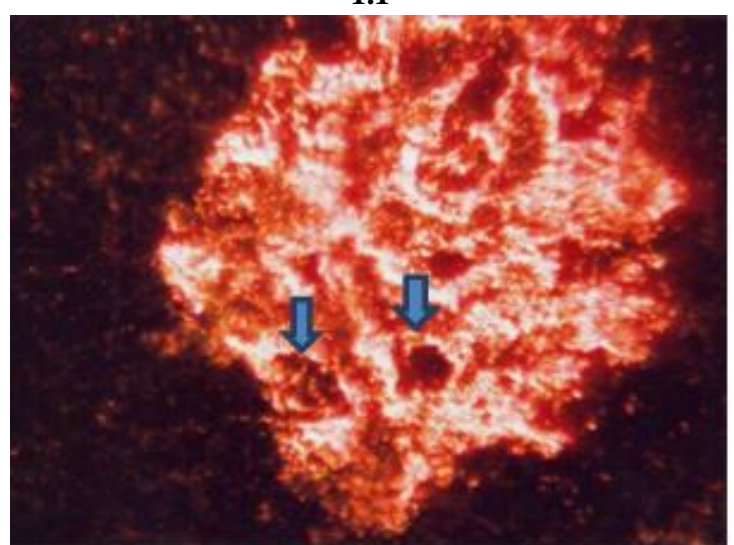

1.3

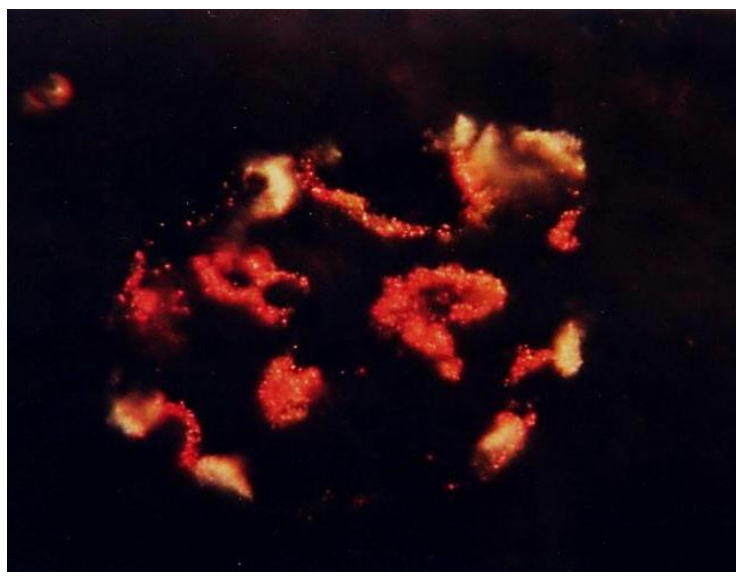

1.5

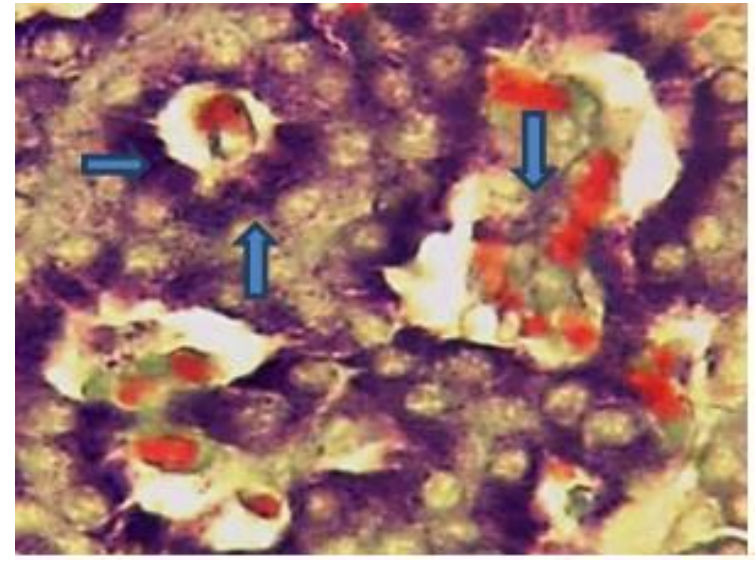

1.2

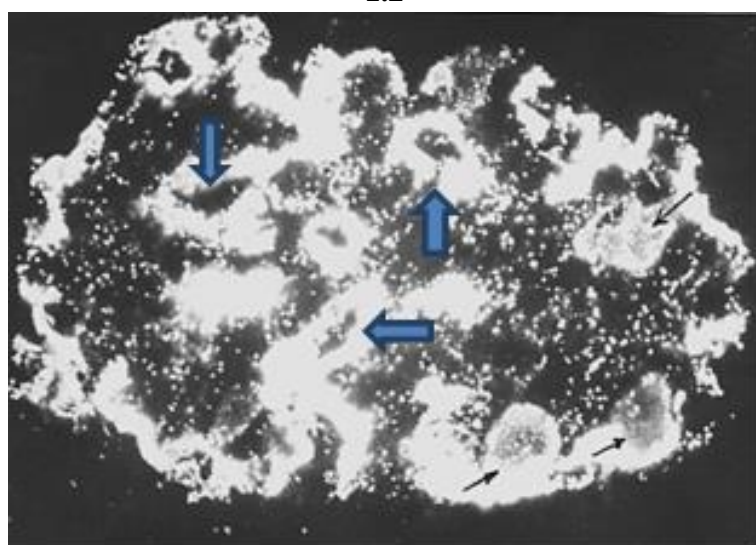

1.4

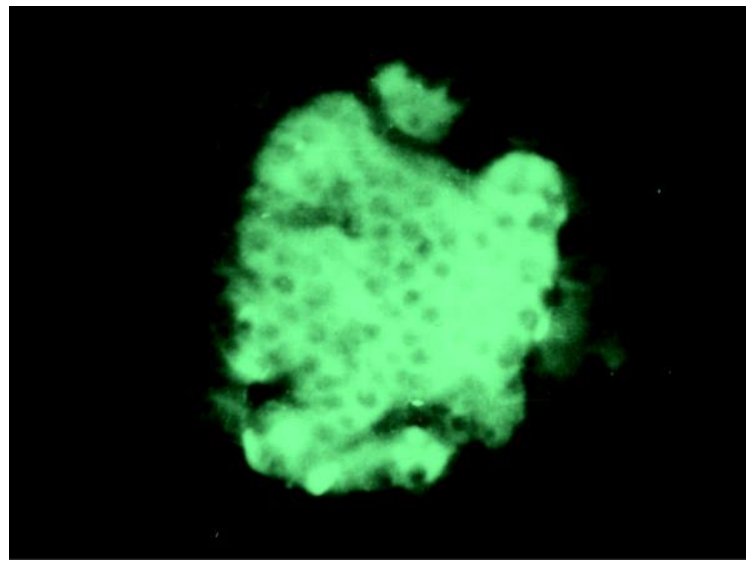

1.6

1.1 and 1.2 - Intact pancreatic islet. Aldehyde-fuchsin. The histostructure and insulin content in B-cells are not changed. The maximum content of deposited insulin in B-cells contacted blood capillaries where insulin maximally concentrated at the pole of the cells contacted capillaries; $\times 280 ; 1.3,1.4$ - Pancreatic islet after administration of diabetogenic dose of Dithizon. Frozen section. The cytoplasm is filled by large number of granules of the Zinc-Dithizon complex, the maximum amounts of which are concentrated around the capillaries; 1.3 slice thickness $7 \mu \mathrm{m} ; 1.4$ slice thickness $-4 \mu \mathrm{m}$; dark microscopy; $\times 280$. 1.5 - Pancreatic islet after administration of the minimal dose of Dithizon - $12.6 \mathrm{mg} / \mathrm{kg}$; Frozen section. Granules of complex Zinc-Dithizon are concentrated around capillaries only. Diabetes not developed; dark microscopy; $\times 280 ; 1.6-$ Fluorescent high specific positive reaction for Zinc-ions with $8 \mathrm{PTSQ}$-green fluorescence; $\times 140$

Figure 1. State of histostructure of B-cells and capillaries after the administration of low doses of Dithizon 


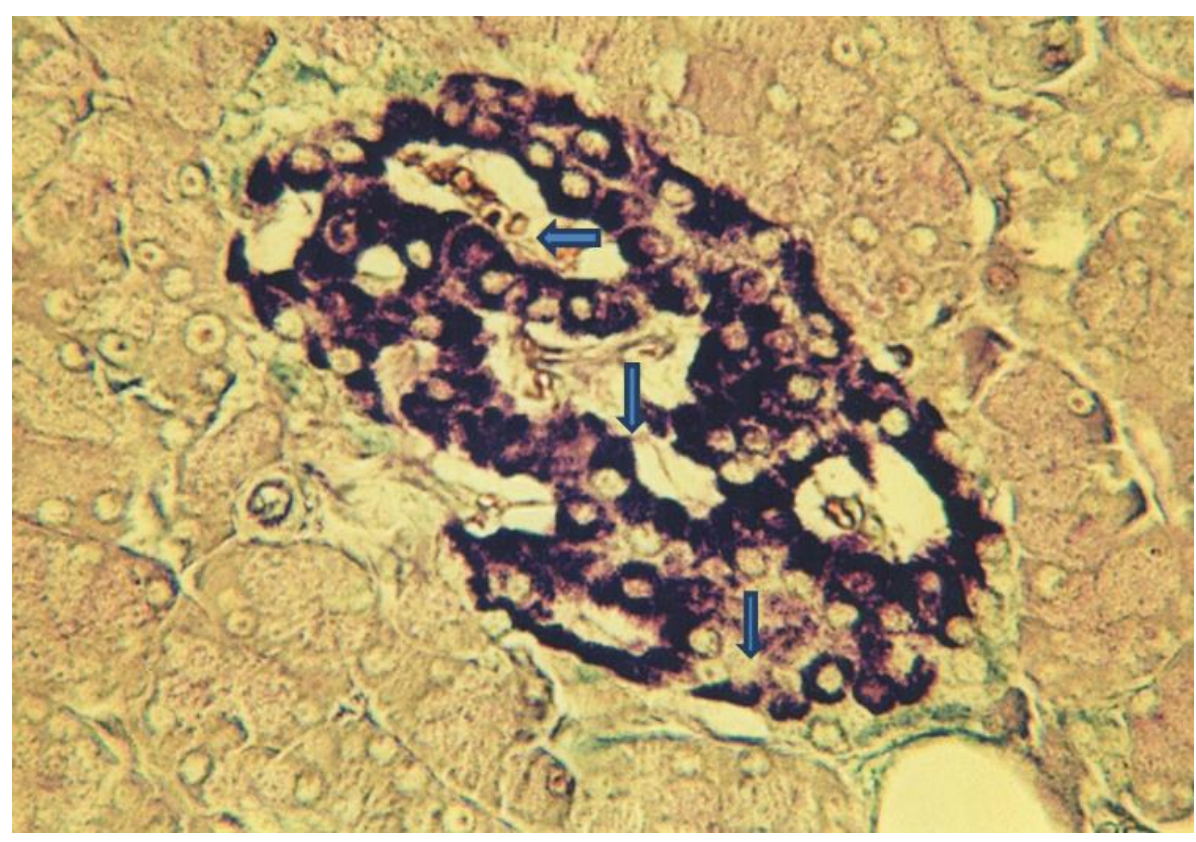

2.1

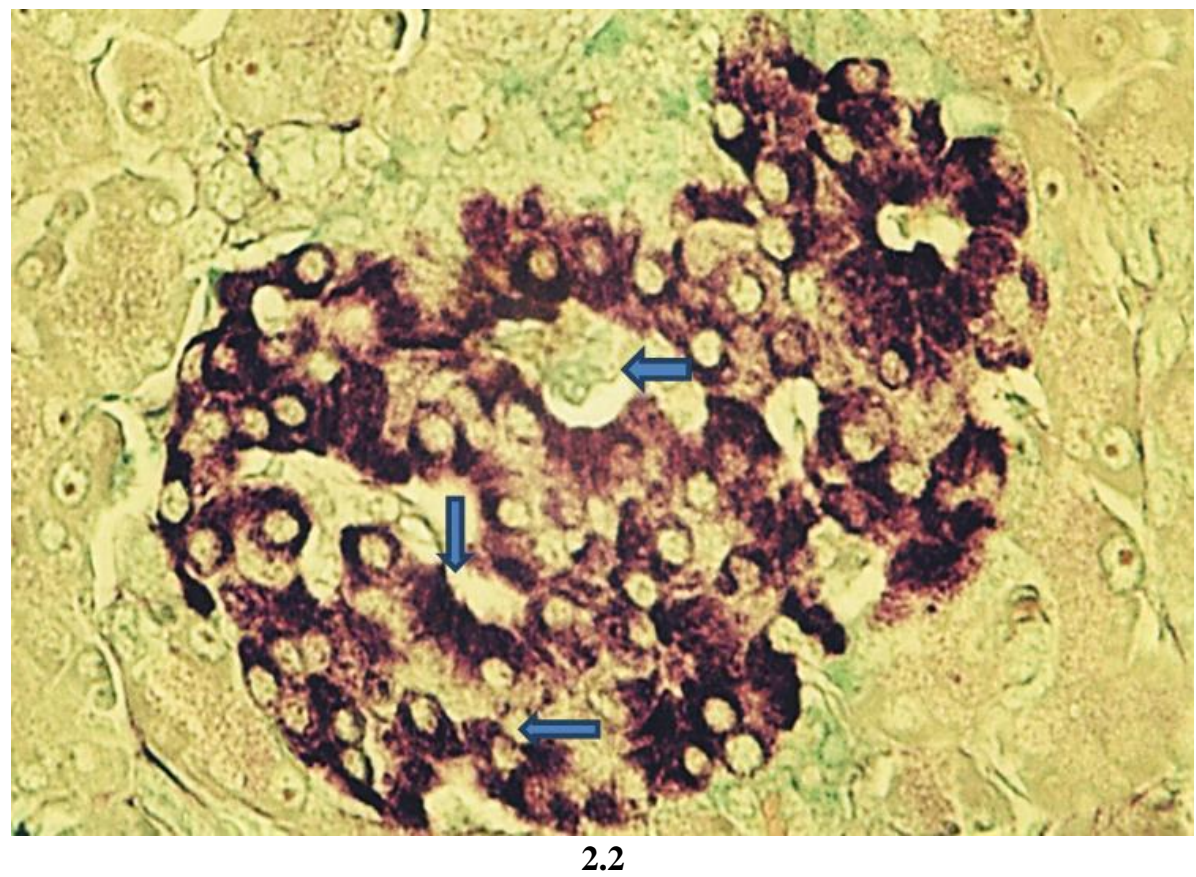

Histostructure and the content of deposited insulin in B-cells without visible changes; in islet capillaries: 2.1 - partial destruction of endothelium; alteration of wall of capillary; 2.2 - adhesion of erythrocytes; perivascular edema

Figure 2. Pancreatic islet after administration of minimal dose of Dithizon $-13.2 \mathrm{mg} / \mathrm{kg}$ after 8 days

Obtained results showed that concentration of the Zinc-Dithizon complex in B-cells localized around capillaries, especially in apical part, causes damage not only to B-cells or their apical part, but also to the wall of the islet capillaries. Obtained results, therefore, demonstrate that vascular changes do not belong to the late complications of diabetes, but primary determined by the damaging effect of DZC not only on B-cells contacted capillaries, but also on the capillaries' wall themselves. An additional, quite convincing proof of this is the fact that these changes arose in the absence of diabetes in these animals, and there could not have been confirmed as late complications of diabetes as disease.

Group 2. The investigation of the content of the Zinc-Dithizon complex in islets after injection of low doses of Dithizon showed the following. Numerous islets were revealed in the sections of pancreas, in which red granules of the zinc-Dithizon complex were found only at the B-cells contacted capillaries, at the zones of 
concentration of deposited form of insulin (Zinc-Insulin complex) that is, in the places where B-cells contact to the islet capillaries' wall, while the other part of cells did not contain the complex. Blood glucose control: a low increasing from $5.2 \pm 0.3 \mathrm{~mm}$ to $6.2 \pm 0.3 \mathrm{~mm}\left(3^{\text {rd }}\right.$ day) and returning to the initial level after 6 and 9 days, to $5.6 \pm 0.5 \mathrm{~mm}$ and $5.3 \pm 0.7 \mathrm{~mm}$, respectively (Table 1). Histostructure: numerous islets of usual sizes were found in the sections. In 8.6-11.7\% of the islets signs of destruction of B-cells at their localization around capillaries were revealed. In the other parts of the cell cytoplasm no visible signs of histological changes were observed. In capillary's endothelium partial damage and destruction of endothelium, altered capillary shape, adhesion of erythrocytes, perivascular edema, the release of erythrocytes outside of capillary, microcirculatory disturbances in the form of hyperemia and stasis were revealed.

Obtained results showed that administration of low doses of DZC to animals didn't result in the development of experimental diabetes, and led to the development of obvious signs of damage of the wall of islet capillaries in combination with the development of microcirculatory disorders.

Vascular disorders in diabetes mellitus are the most common and lead to the development of complications accompanied by disability. As a rule, these are late complications of diabetes, developing not in the initial period but through long periods of time, often in years. In our experiences vascular disorders of the islet capillaries developed in absence of diabetes and were characterized by the selectivity of damage of the capillary wall, while islet cells remained generally intact and in the absence of signs of diabetes. Results showed that in the genesis of development of alteration of capillary's wall contacted Zinc-Dithizon complex, which at low doses is formed only in B-cells, the contact of complex with capillary endothelium is of direct importance.

\title{
Conclusion
}

Thus, these vascular changes can in no way be attributed to the late complications of diabetes, especially since it did not develop. Additional confirmation of this possibility may be due to the following reasons:

1) high toxicity of Zinc-Dithizone complexes for B-cells;

2) vascular changes in pancreatic islets in experiments when diabetes in animals has not yet developed that demonstrate why these changes cannot be estimated as late complications of diabetes.

\section{References}

1 Bloomgarden Z.T. Developments in diabetes and insulin resistance / Z.T. Bloomgarden // Diabetes Care. — 2006. — Vol. 29. - P. 161-167.

2 Балаболкин М.И. Лечение сахарного диабета и его осложнений (руководство для врачей) / М.И. Балаболкин, Е.М. Клебанова, В.М. Креминская. - М.: Медицина, 2005. - 511 с.

3 Meyramov G.G. Vascular and Histological Changes in Pancreatic islets in diabetes caused by xanthurenic acid / G.G. Meyramov, A.A. Kikimbaeva // Diabetes. — 2013. — Vol. 62, No. 6. - P. 751.

4 Meyramov G.G. Diabetogenic Metabolits of Tryptophan / G.G. Meyramov, A.S. Shaybek, A.G. Abdraimova // Bulletin of the Karaganda University. Series Biology. Medicine. Geography. — 2016. — No. 4 (84). - P. 44-55.

5 Kvistberg D. Staining of insulin with aldehyde fucshin / D. Kvistberg, G. Lester, A. Lasarov // J. Histochem Cytochem. 1966. - Vol. 14. - P. 609-611.

6 Ortman R. Concerning the staining properties of aldehyde basic fucshin / R. Ortman, W. Forbes// J. Histochem. — 1966. Vol. 14. - P. 104-111.

7 Божевольнов Е.А. 8-пара(толуолсульфониламино)хинолин люминесцентный реактив на цинк и кадмий / Е.А. Божевольнов, Г.В. Серебрякова // Химические реактивы и препараты. - М., 1961. — С. 36-42.

8 Meyramov G.G. The High Specific Method for Revealing of Zinc in Pancreatic B-cells / G.G. Meyramov, G.T. Tusupbekova, R.G., Meyramova // Diabetes. — 1991. — Vol. 40, No. 6. - P. 65.

\author{
Г.Г. Мейрамов, В.И. Корчин, А.С. Шайбек, А.А. Кикимбаева, Д.А. Мейрамова
}

\section{Ұйқы безі аралдарындағы қан капиллярларының эндотелийіне диабетогендік хелаторлардың зақымдау әсерінің механизмі туралы}

\footnotetext{
Авторлар диабеттік мырышбайланыстырғыш заттарды (ДМЗ) жануарларға тағайындау тек В-жасушаларының жойылуымен және өлімімен ғана емес, сонымен қатар В-жасушаларымен байланыс орнында ұйқы безі аралдарының капиллярларының морфологиялық өзгерістерінің дамуымен (капиллярлық эндотелий учаскелерінің бұзылуы, капиллярлық аралық пішіннің өзгеруі, эритроциттер адгезиясы, периваскулярлық ісіну, гиперемия) өзгеруімен бірге жүретінін көрсеткен. Қан тамырдағы өзгерістер -
} 
бұл әдетте қант диабетінің кеш асқынуы. Сұраққа жауап беру үшін: артериялық капиллярлардағы сипатталған өзгерістер қант диабетінің кеш асқынуымен (1) сипатталады ма немесе ДМЗ (2) тікелей зақымдайтын әсерінің нәтижесі ме, яғни, ДМЗ төмен дозалары жануарларда қант диабетін туғызбайтын капилляр қабырғасымен байланыста болатын жасушалар тек В-полюсінде улы мырыш-дитизон кешенін құрауда қолданылады. Бұл жағдайда қант диабеті болмаған кезде капилляр қабырғасы зақымданатыны көрсетілді, бұл ДМЗ-ның тек В-жасушаларына ғана емес, сонымен қатар арел капиллярларының эндотелиясына да тікелей әсерін көрсетеді. Бұл қант диабетінің осы түрлерінің дамуының тікелей себебі емес, бірақ ұйқы безі аралдарындағы микроциркуляцияның бұзылуымен және тиісінше аурудың ағымының нашарлауымен бірге жүруі мүмкін.

Кілт сөздер: В-жасушалар, эндотелий, капиллярлар, диабетогенді мырышбайланыстырушы заттар, гистофлюориметрлік кешен.

\title{
Г.Г. Мейрамов, В.И. Корчин, А.С. Шайбек, А.А. Кикимбаева, Д.А. Мейрамова \\ О механизмах повреждающего действия диабетогенных хелаторов на эндотелий капилляров крови в островках поджелудочной железы
}

\begin{abstract}
Авторами показано, что введение диабетогенных цинк-связывающих веществ (ДЦВ) животным сопровождается не только деструкцией и гибелью В-клеток, но и развитием морфологических изменений капилляров панкреатических островков в месте контакта с В-клетками (деструкция участков эндотелия капилляров, изменение формы просвета капилляров, адгезия эритроцитов, периваскулярный отек, гиперемия). Сосудистые изменения обычно являются поздними осложнениями диабета. Для ответа на вопрос: «Являются ли описанные изменения капилляров островков поздним осложнением диабета (1) или это результат прямого повреждающего действия ДЦВ (2)?» использованы низкие дозы ДЦВ, которые не вызывают диабета у животных, формируя токсический комплекс цинк-дитизон только на полюсе В-клеток, контактирующем со стенкой капилляров. Показано, что и в этом случае стенка капилляров повреждается в отсутствие диабета, что свидетельствует о прямом повреждающем действии ДЦВ не только на В-клетки, но и на эндотелиум капилляров островков. Данный факт не является прямой причиной развития указанных форм диабета, но может сопровождаться нарушениями микроциркуляции в панкреатических островках и, соответственно, ухудшением течения заболевания.
\end{abstract}

Ключевые слова: В-клетки, эндотелий, капилляры, диабетогенные цинксвязывающие вещества, гистофлюориметрический комплекс.

\section{References}

1 Bloomgarden, Z.T. (2006). Developments in diabetes and insulin resistance. Diabetes Care, 29; 161-167.

2 Balabolkin, M.I., Klebanova, E.M., \& Kreminskaya, V.M. (2005). Lechenie sakharnogo diabeta i ego oslozhnenii (rukovodstvo dlia vrachei) [Treatment of diabetes mellitus and its complications (guide for doctors)]. Moscow: Meditsina [in Russian].

3 Meyramov, G.G., \& Kikimbaeva, A.A. (2013). Vascular and Histological Changes in Pancreatic islets in diabetes caused by xanthurenic acid. Diabetes, 62 (6), 751.

4 Meyramov, G.G., Shaybek, A.S., \& Abdraimova, A.G. (2016). Diabetogenic Metabolits of Tryptophan. Bulletin of the Karaganda University. Series Biology. Medicine. Geography, 4 (84); 44-55.

5 Kvistberg, D., Lester, G., \& Lasarov, A. (1966). Staining of insulin with aldehyde fucshin. Journal of Histochemistry and Cytochemistry, 14; 609-611.

6 Ortman, R., \& Forbes, W. (1966). Concerning the staining properties of aldehyde basic fucshin. Journal of Histochemistry, 14; $104-111$.

7 Bozhevolnov, E.A. \& Serebryakova, G.V. (1961). 8-para(toluolsulfonilamino)khinolin lyuminestsentnyi reaktiv na tsink i kadmii [8-para(toluenesulphonylamino)quinolin luminescent reagent for zinc and cadmium]. Khimicheskie reaktivy i preparaty - Chemical reagents and drugs. Moscow [in Russian].

8 Meyramov, G.G., Tusupbekova, G.T., \& Meyramova, R.G. (1991). The High Specific Method for Revealing of Zinc in Pancreatic B-cells. Diabetes, 40 (6); 65. 